\title{
2. Treading Water in Rapids? Non-Governmental Organisations and Resistance to Neo-Liberalism in Pacific Island States
}

\section{Claire Slatter}

Today we are so mesmerized by globalisation and the World Trade Organisation that development has become a very technical pursuit. It's no longer a question of creative thinking, or of having a vision and trying to pursue that vision (never mind about its practicalities) which I think was the spirit of the 1960s and 1970s. There was no limitation on visions then.

- Amelia Rokotuivuna, Pacific activist for peace and justice, February 2005

\section{Introduction}

In the current new world order of neo-liberalism, civil society organisations have emerged as an important countervailing force to the power of multilateral institutions and transnational corporations, and as watchdogs on states. The global movement against neo-liberalism and its manifestation in economic and trade liberalisation is an unprecedented international resistance movement comprising a broad range of civil society organisations, social movements, development NGOs and public interest groups opposed to the ideological, economic and political forces that have been reshaping the world in the past 16 or so years with devastating impacts on the lives of millions of people, and the environment. The movement is in many respects a post-Cold War sociopolitical formation in which old hierarchies, ideological divisions and dogmas have no place and are strongly contested by contemporary definitions and understandings of human rights, insistence on transparent, democratic practice and participatory leadership, respect for diversity, and opposition to extremism and fundamentalism of all kinds. Transcending nation-states in its mobilisation of citizens of the globe, it's also a distinctly 21st-century movement, whose organisation has been made possible by the forces of globalisation itself. Its vision, expressed in the World Social Forum slogan 'Another World is Possible', underscores its unequivocal rejection of the 'there-is-no-alternative' dictum and affirms a belief in and commitment to alternatives. 
As realities in the Pacific region have begun to change in the past decade as a consequence of the impacts of economic globalisation and the implementation of neo-liberal policies by Pacific Island governments, a handful of NGOs and civil society organisations in the region have begun to critically analyse economic and trade policy, to link with organisations and movements working on the same issues in other regions or globally, and to challenge governments over 'reforms' being implemented on the direction or advice of multilateral and bilateral donors. In comparison with the far larger number of organisations and individuals in the region engaged in advocacy and defence of democracy and human rights, however, this fledgling 'movement' against neo-liberalism and economic and trade liberalisation lacks a critical mass, as well as a clear agenda and the resources to pursue it.

This paper contexualises the emergence of 'resistance' to mainstream economic thinking in the Pacific region against the backdrop of the global movement against neo-liberalism, on the one hand, and a region-wide program of economic 'reform' on the other. It advances reasons for the sporadic nature of resistance to current economic orthodoxy in Pacific Island countries, highlighting recent challenges made by regional NGOs and some of the difficulties NGOs have playing a watchdog role in relation to economic and trade policy in Pacific Island states. It suggests that civil society organisations need to equip themselves to play a much stronger advocacy role in influencing economic and trade policy, but in order to be able to do this effectively they first need to sharpen their understanding of the present global political economy and the forces that are shaping it, and develop a clear vision of the kind of future they want Pacific people to enjoy. With Pacific governments rapidly committing themselves to liberalisation agreements that have not been debated publicly, intermittent or half-hearted resistance by NGOs is meaningless and tantamount to trying to tread water in rapids.

\section{Global civil society challenges to neo-liberalism}

A philosophy that hinges on a belief in individualism, free enterprise, lowered taxes, deregulated economies and labour markets, and small government, neo-liberalism idealises free markets and the market-friendly State and privileges the 'private sector' or corporate interests at the expense of public interests and welfare. For the past two decades, aided by the so-called Third-World debt crisis since the early 1980s and the collapse of socialism from 1989, neo-liberal economic policies have been successfully imposed or peddled in countries across the developing world by the IMF, the World Bank and its regional derivatives and donor agencies alike. The progressive liberalisation of markets since 1995 through negotiated trade rules among member states of the WTO has effectively enshrined neo-liberal ideas within a new, albeit strongly contested, framework of international law, while neo-liberal discourses on 'growth', 'efficiency', 'reform' 
and 'governance' emerging from World Development Reports ${ }^{l}$ have come to dominate development thinking.

The movement against economic globalisation and neo-liberalism emerged in response to mounting concerns about the serious social and economic crises and extreme inequalities resulting from the implementation of restructuring and liberalisation policies across the developing world, the injustice of Third-World debt, and the growing power of international financial institutions, the WTO, and transnational corporations. The unprecedented facility for global organisation made possible by the Internet was a key factor in mobilising the movement and continues to be critical to its organisation, growth and effectiveness. Equally or perhaps more significant in spawning this movement was the series of UN development conferences in the 1990s that engaged thousands of NGOs from the First and the Third World in its processes and saw the emergence of new frameworks for global policy-making (particularly the rights-based approach) as a result of understandings and agreements achieved through negotiations that took place within them (UN System and Civil Society 2003).

Considered one of the key drivers of increased civil society engagement in global policy-making and the shaping of world public opinion, the UN conferences and their preparatory and review processes gave unprecedented opportunities to NGOs and civil society groups to not only influence, and indeed set, global policy agendas, but to meet and share information and analyses among themselves, build alliances, networks and campaigns, and strategise. ${ }^{2}$ Although splits and tensions among the NGOs certainly emerged, replacing the 'single global cleavage of the Cold War ... by multiple fault lines' (ibid.), the conferences contributed to the elaboration of what might be considered a global civil society agenda, in which reforms in global governance institutions, including the UN itself, became a key goal. ${ }^{3}$ More importantly, the plans of action that emerged from conference negotiations provided NGOs with considerable leverage to hold national governments and multilateral institutions to account on commitments made at the conferences. This marked a turning point for many NGOs and, undoubtedly, one of the most significant outcomes of the UN conferences of the 1990s was the empowering of NGOs and the metamorphosis of many of them into effective lobbying organisations, equipped with a keen understanding of global political economy, an unequivocal human rights framework, and the necessary research and analytical capacity to play an advocacy and a watchdog role in global, regional and national policy arenas.

Outside the UN, civil society organisations and NGOs targeted WTO Ministerial Conferences in Seattle, Doha and Cancun, protesting against the WTO's undemocratic processes, unfair trade rules, privileging of corporate interests and devastation of livelihoods. A successful global campaign by civil society organisations had, in 1998, torpedoed an EU-proposed multilateral agreement 
on investment under the WTO, which would have given multinational corporations far-reaching rights, including the right to sue states. The campaign was triggered by the leaking of details of the proposed agreement to a Canadian NGO. In 1999 and 2003, this global 'movement' for economic justice and fair trade, drawing support from a broad cross-section of global civil society, including feminists, environmentalists, human rights activists, indigenous, labour and farmers' movements, contributed to derailing WTO ministerial talks in Seattle and Cancun. Indeed, by 2003, civil society campaigns dealing with debt, fair trade and development, health before patents and profits, and corporate social responsibility had begun to show effect, testifying to the collective power of global civil society as a countervailing force against the growing power of multilateral institutions and corporations, and as a watchdog on states.

As amorphous as the movement against neo-liberalism and economic globalisation is, its diverse 'membership' does cohere around an unequivocal renunciation of neo-liberal orthodoxy and the new world order being constructed on this blueprint. This is evident in the already cited slogan of the World Social Forum (WSF). An 'impressive General Assembly of civil society' (UN System and Civil Society 2003: 16), which began to convene annually in Porto Alegre, Brazil, from January 2001 as a developing-world counter to the World Economic Forum in Davos, Switzerland, the WSF represents an annual gathering of forces of an unprecedented global protest movement. ${ }^{4}$ Latin American sociologist Boaventura de Sousa Santos, in a detailed political analysis of WSF, explains its significance in simply 'claiming the existence of alternatives to neo-liberal globalisation'. The WSF, he points out, holds 'no clearly defined ideology either in defining what it rejects or what it asserts'; yet, in a context in which 'the conservative utopia prevails absolutely', to 'affirm the possibility of alternatives' is better than to define them (Boaventura 2003). In Boaventura's view, the WSF is an entirely 'new social and political phenomenon' that is non-hierarchical and even leaderless, in that no one person or group can assume leadership or speak in its name. In their book on the second WSF, Fisher and Ponniah, in a similar vein, claim that the WSF represents 'a new democratic cosmopolitanism, a new anti-capitalist transnationalism, a new intellectual nomadism, a great movement of the multitude' (Fisher and Ponniah 2003: xvi).

Certainly the WSF's political and moral force lies as much in the diversity and multiplicity of resistant voices that emerge strong and clear from within it, albeit with some discordant notes, ${ }^{5}$ to challenge hegemonic globalisation and insist on alternatives, as it does in the open, participatory processes put in place and implemented by organisations and groups which comprise the WSF's International Council. The numbers of people attending the WSF have also grown exponentially since 2001, increasing fivefold from 20,000 participants in 2001 to 100,000 in 2003, with the number of workshops and countries represented rising from 420 to 1,286 , and 117 to 156 , respectively, in the same period. Yet 
NGOs are the organisational forms through which social movements function in today's world. And it is the sustained and dedicated work of a large number of NGOs concerned about the current world order that succeeds in convening thousands of civil society opponents of economic globalisation at the WSF each year. Most of these NGOs play an active watchdog role in relation to multilateral institutions, OECD states, regional and other groupings of states in the First and Third World, and keep a watching brief on the various global and regional policy-making fora.

Only a handful of Pacific NGOs have sent representatives to the WSF but several more have engaged in other events organised by global Thirld-World networks working on globalisation and trade liberalisation, or have otherwise become linked to regional and global networks involved in advocacy for global economic justice. Yet very few NGOs in the region have engaged in research, advocacy or activism on these issues at home, much less organised in a sustained way at the regional level to influence the processes of regional economic and trade policy-making that have been in evidence since the mid-1990s. The rest of this paper explores why this is so, against the backgrounds of neo-liberal influence and a region-wide and donor-driven program of 'reform' in the Pacific, and the issues currently occupying NGOs in the region. It is suggested that the primary challenges to regional and national NGOs in the Pacific are to firstly equip themselves to engage critically in debates on economic and trade policy, and secondly to find and use their critical voice.

\section{Neo-liberal reform and civil society resistance in the Pacific region}

Consensus among multilateral and bilateral donors in the region on the Pacific Island states' best economic policy options saw the prioritisation of economic restructuring in donor aid programming from the mid-1990s. ${ }^{6}$ Inspired by two World Bank reports on economies in the region (World Bank 1991, 1993), the urgings of neo-liberal policy advocates in Australian and New Zealand academia, ${ }^{7}$ and the restructuring experience of New Zealand, 'economic reform' (as it's euphemistically termed in the Pacific) has been underwritten primarily by the ADB through a program of lending that is now being strongly criticised for having saddled Pacific Island states with burdensome debts. ${ }^{8}$

The Pacific Islands Forum, formerly the South Pacific Forum, has played a key role in regional economic restructuring, functioning as a channel for the diffusion of neo-liberal economic ideas and thinking among Pacific Island leaders, and as the principal implementing agency in the externally driven program of 'reforms'. 9 From 1999, the work of the Pacific Islands Forum Secretariat began to focus increasingly on trade liberalisation and compliance with WTO principles and trade rules - two regional trade agreements, the Pacific Island Countries Trade 
Agreement (PICTA) and the Pacific Agreement on Closer Economic Relations (with Australia and New Zealand; PACER), emerged from Secretariat processes. After the signing of the Cotonou Agreement between African, Caribbean and Pacific (ACP) countries and the EU in 2000, and the inclusion of six more Pacific Island states in the ACP group, the Secretariat also assumed responsibility for coordinating negotiations between Pacific ACP countries and the EU on a Regional Economic Partnership Agreement, and subsidiary agreements. Meanwhile, with Tonga successfully completing its WTO accession requirements in November 2005, Vanuatu requesting a reopening of the WTO accession package it agreed to and then shelved in 2001 (with a view to renegotiating the terms on which it joins the WTO), and Samoa preparing to accede, Pacific states are moving rapidly down the path of liberalisation.

Although discordant notes have been heard within the Pacific Islands Forum ${ }^{10}$ and Pacific Island leaders were vexed about Australia and New Zealand's manipulations to secure PACER, ${ }^{11}$ and although Vanuatu officials have expressed strong criticisms of ADB-designed reform programs (Gay and Joy n.d.), the Forum Secretariat remains committed to pushing economic 'reform' and trade liberalisation in the region, national governments appear to still be firmly on board for the rest of the regional reform voyage, and 'reform-speak' has become the dominant discourse in the region, within and outside government.

Publications of substantial critiques of current economic policy are rare. Mainstream academia in the Pacific has largely taken no issue with 'reform' policies or their economic rationale. The process of economic restructuring in the region has indeed been facilitated by the virtual absence of contrary academic opinion. ${ }^{12}$ Not only have most regional economists failed to debate, much less critique, the neo-liberal economic arguments of economic 'reform' advocates within governments and intergovernmental institutions, several have been active advocates of these policies. The recent restructuring and marketing of programs and jobs at the University of the South Pacific has made many academics beneficiaries of market-based 'reforms', introducing new inequalities through non-transparent processes of private negotiation on individual employment contracts that would have been considered unfair in a previous era.

There is a general dearth of information in the public domain on the origins, objectives and implications of structural adjustment policies, little if any coverage in the mainstream media of the negative impacts of such policies or of trade liberalisation elsewhere in the developing world, and next to no informed debate on these issues in national parliaments. The finding by researchers who produced the USP Report on Strengthening Regional Cooperation through Enhanced Engagement with NGOs that 59 per cent of participants in the consultations they held knew 'little/nothing about trade' is not surprising; nor is the finding that 
63 per cent knew 'little/nothing about what the Forum Secretariat does' (Sutherland et al. 2005).

Organised civil society opposition to 'reform' in Pacific Island countries has tended to be sporadic, confined largely to national contexts, and occurring at different times, over different issues and involving different protagonists, such that solidarity from civil society organisations in other parts of the region has most often been limited if not completely absent. Moreover, in most Pacific Island countries, pressing national issues have often taken precedence over programs of 'reform', claiming the attention and energy of NGOs. Even where broad coalitions of NGOs have emerged, such as in Fiji with the NGO Coalition on Human Rights and the Human Rights and Democracy Movement in Tonga, challenging economic and trade policy has not really been part of their remit. Ironically, precisely because the strongest NGOs are preoccupied in pro-democracy, anti-corruption struggles, so-called economic 'reform' has been able to proceed largely unchallenged. Even more ironically, these movements often cite political conditionality and good governance discourses in support of their causes, without fully appreciating their neo-liberal nuances, association with deregulation/liberalisation policies and their implications.

The earliest resistance to 'reform' policies in Fiji occurred immediately after the military coups in 1987 and came from the trade union movement, which challenged the repressive labour laws imposed by decree and tax-free factories, two of the earliest elements in the post-coup government's deregulation program, and subsequently opposed other dimensions of structural adjustment, including taxation 'reforms', corporatisation and privatisation of state entities, and public sector 'reform'. In addition to soliciting solidarity action against the labour decrees, the Fiji Trades Union Congress published statements in the press, and when permits could be obtained organised public protests, all of which were usually portrayed as oppositional 'political action' because of the Congress's close links with the Fiji Labour Party, which had been deposed in the coup.

The leading and most persistent critic of economic restructuring from within the churches in the Pacific has been Fiji-based Father Kevin Barr, whose prolific writings, on behalf of the Fiji Council of Churches' Research Group, the Peace, Justice and Integrity of Creation project of the Catholic Church, and, more recently, the Ecumenical Centre for Research, Education and Advocacy (ECREA), combine a strong critique of economic globalisation based on Christian social theology with evidence-based analysis of growing poverty in Fiji and the region. Largely due to the publications and advocacy work of Fr Barr and those with whom he works, church-based organisations can be credited with tracking and critiquing current economic policy and its impacts in the region. This work has not been uncontested, however, and the metamorphosis of the Fiji Council of 
Churches' Research Group into ECREA gave Fr Barr and others in the Church working on economic justice issues a far freer hand.

Violent opposition to economic restructuring occurred in PNG in 1995 when massive protests were staged against an IMF/World Bank-proposed Land Mobilisation Program aimed at 'freeing up' land and providing security of tenure or property rights. Six years later, in 2001, 13 days of rioting and protests over government plans to retrench one-third of the PNG Army on the advice of a Commonwealth Eminent Persons Group, funded by Australia and led by a former New Zealand Secretary of Defence (Standish 2001), saw four students shot and killed. ${ }^{13}$

In October 2002, after pressure from various official quarters, the private sector and civil society, and the realisation that it had 'given away too much' (Kelsey 2004a), the Vanuatu Government shelved a completed WTO accession package. The accession negotiations, which began after Vanuatu applied to join the WTO in 1995, had subjected Vanuatu to a range of WTO-plus demands from the WTO Working Party, including demands for radical liberalisation of services. ${ }^{14}$ In Oxfam New Zealand's view, acceding under the terms agreed to by Vanuatu would have exposed the country to 'the worst kind of corporate cream-skimming in the education and hospital sectors' (Oxfam NZ 2005). Vanuatu's supposedly publicly endorsed Comprehensive Reform Program, which began in 1997 and was underwritten by an ADB loan approved in 1998, had in large part been aimed at preparing Vanuatu for WTO accession, as indicated by the tariff reductions and value-added tax put in place by the Vanuatu Government as part of ADB conditionality (Oxfam NZ 2005: 10).

The most recent civil society challenges to reform and trade liberalisation have occurred in Tonga. A massive strike by civil servants in 2005 was triggered by the impacts of public sector reforms, which had introduced large remuneration increases for very senior public servants. The success of the strike, together with the growing strength of Tonga's Democracy Movement and public disenchantment with the impacts of a consumption tax (introduced to offset expected revenue losses from tariff reduction once Tonga joined the WTO), encouraged a broad coalition of NGOs, trade unions and church organisations to convene a workshop in late October on the implications of Tonga's accession to the WTO under terms agreed to during WTO Working Party negotiations, and subsequently to organise a public campaign to try to stop the Tongan Government from proceeding with the accession plans. Though the campaign did not succeed in halting the accession process, it raised public understanding of Tonga's WTO obligations and their social and economic implications.

Organised opposition to neo-liberalism and 'reform' at the regional level has until recently been largely absent, intermittent expressions of concern notwithstanding. Although an annual NGO Parallel Forum, convened since 1995, 
at the same time and in the same location as the Pacific Islands Forum, provided an opportunity to regional NGOs to closely monitor and track the work of the Forum Secretariat in driving the regional reform agenda, and to advance policy critiques and an alternative vision, participating organisations seemed to be preoccupied with their own work programs, which did not include keeping a watching brief on regional economic policy commitments and their implementation at the national level. Criticisms of the 'reform' agenda made at Parallel Forums were therefore not sustained by any substantial research, analysis and advocacy work carried out regionally, or even nationally, by way of follow up. From 2001, a number of initiatives saw a stepping up of regional-level responses to 'reform' and trade liberalisation. In 2001, after a regional consultation convened by the World Council of Churches in Geneva, Pacific churches adopted a collectively authored platform document to which Fr Barr contributed, critiquing economic globalisation and the neo-liberal ideas and values that fuel it. Titled 'Island of Hope' — The Pacific Churches' Response on Alternatives to Economic Globalisation, the document asserted Pacific economic values of redistribution or resource-sharing and communal 'ownership' and social values of sharing responsibility for the welfare of kin, and investing in social solidarity. The same year, a Regional Consultation on Globalisation, Trade, Investment and Debt, organised by ECREA and held in Nadave, Fiji, brought together regional NGOs working on development and rights, and triggered the creation of the Pacific Network on Globalisation (PANG) with the objective of conducting research, analysis and advocacy on economic and trade policy issues.

\section{Recent NGO challenges to Pacific governments and the Pacific Islands Forum Secretariat}

The formation of PANG as a regional network tasked by its Steering Committee with raising public debate with a view to influencing decisions made at the regional level in relation to economic and trade policy, saw the beginning of substantial criticism from civil society of Pacific Island leaders and the Pacific Islands Forum Secretariat. PANG began by challenging the Pacific Islands Forum Secretariat (PANG 2002) on its misrepresentation of PICTA and PACER, and the less than independent social impact study of PICTA it had commissioned and accepted from two University of the South Pacific professors who underplayed its negative impacts (Forsyth and Plange 2001). The network subsequently engaged Auckland University law professor Jane Kelsey, New Zealand's leading critic of structural adjustment and the WTO, to undertake a critical analysis of PACER and its likely impacts on Pacific Island states.

Two hard-hitting reports on PACER were produced for PANG that year by Kelsey (Kelsey 2004a, 2004b) after 'extensive interviews with politicians, diplomats, trade officials, consultants, business people and NGOs, as well as published and unpublished reports and files at the NZ Ministry of Foreign 
Affairs' (PANG Media Advisory 2004). They were delivered to Pacific Island governments (several of whom quietly expressed appreciation to PANG for the work and alternative perspective), and disseminated widely among NGOs in the region with the aim of empowering 'people of the Pacific region to engage in critical decisions on trade and economic agreements that will decide their future' (ibid.). The next year Kelsey was hired by the World Council of Churches' new Pacific Office in Suva to produce a 'People's Guide to the Pacific's Economic Partnership Agreement Negotiations with the European Union', and the resulting publication was similarly publicised and disseminated widely throughout the region (Kelsey 2005a). Since losing its very able and dynamic coordinator, Stanley Simpson, to the UN Development Program (UNDP) at the end of 2004, PANG's work has lost some of its momentum, although its substantial contribution to raising public awareness of regional economic policy and trade agreements and encouraging debate, critique and civil society resistance, is still being realised.

In the past two years, and largely to comply with obligations under the Cotonou Agreement to consult with civil society, the Forum Secretariat has been including selected NGO representatives in stakeholder consultations and in some advisory or reference groups in relation to the Economic Partnership Agreement process. At the same time, however, a process emanating largely from outside the Pacific Islands, involving consultations by an Eminent Persons' Group, largely left out civil society and inspired a controversial 'Pacific Plan' that drew strong objections from regional NGOs, which organised themselves for an unprecedented confrontation with Pacific governments and the Forum Secretariat. The plan, adopted by the Pacific Islands Forum Meeting in Port Moresby in October 2005, is a 'road map' for further trade liberalisation in the region under PICTA, PACER and the Economic Partnership Agreement with the EU.

Presented as if it had originated from Forum Island leaders themselves, and marketed actively through a series of national consultations intended to secure maximum public ownership, the Pacific Plan's authorship was later revealed to reside in the Australian Department of Foreign Affairs and Trade. ${ }^{15}$ Pacific regional NGOs reacted vehemently to the Pacific Plan, issuing a statement endorsed by a large number of organisations ${ }^{16}$ calling for a two-year moratorium on the plan to enable 'a more comprehensive and genuine consultation process' to take place and 'informed consent' to be obtained from Pacific people (Pacific Magazine 2005). The NGO statement criticised the plan for claiming to 'treasure the diversity of the Pacific' and to seek a future in which 'its cultures, traditions and religious beliefs are valued, honoured and developed' while completely disregarding these. It also slammed the processes through which the Pacific Plan emerged, public support was being mobilised, and the haste with which it was being pushed through. Greenpeace Oceans campaigner Lagi Toribau summarised the NGO's substantial critique well with her comment after the Port Moresby meeting that despite considerable rhetoric about security in the plan, it failed 
to deliver 'true security for Pacific Island communities, such as health, food and real energy security' (Hamed 2005). What was missing from the NGO statement was a more substantial critique of the Pacific Plan and how it linked with the 'reform' and liberalisation agendas; and the statement was the weaker for the absence of a substantial critique of what the plan was really about.

A parallel Civil Society Forum held in Port Moresby before the official forum meeting saw regional and national civil society leaders repeat their longstanding request for a formal arrangement through which to channel their concerns to Pacific leaders at the forum meeting each year. NGOs do not have observer status at any sessions of the official forum meetings, although some of them, such as the Pacific Concerns Resource Centre, have been able to gain access as accredited 'journalists' for their own newsletter. Nor are NGOs consulted regularly by governments in the region. With national policy being set increasingly through agreements and commitments made by governments at regional intergovernmental meetings, and most often without reference to national parliaments, some regular form of civil society consultation at the regional level is called for, as is a system of accrediting NGOs to observe at least some sessions of the official meeting, with the opportunity to try to influence debates and decision making. Until now, NGOs have had to content themselves with the arrangement, followed at the 2005 forum meeting, of formally presenting their concerns and statements to a representative of the Forum Secretariat (in 2005, to Secretary-General, Greg Irwin), who relays them to heads of governments at the official meeting. They have been immensely grateful for the attention paid to them by New Zealand Prime Minister, Helen Clark, who has, since the 2003 Pacific Islands Forum, taken the time to pay the Parallel Forum a visit. The goodwill that this has engendered among regional NGOs towards the New Zealand Prime Minister is evident, and has softened criticisms that might otherwise be directed at New Zealand for its role in pushing the Pacific Plan.

The exclusion of Pacific NGOs from observing at intergovernmental meetings of the Pacific Islands Forum stands in stark contrast with the access and representation NGOs have come to enjoy, and expect, in UN processes. At the same time, securing representation or an avenue for regular consultation with governments at Forum meetings without making the necessary investment in collective research and analysis of economic and trade policy issues - to ensure that access to the forum meetings was utilised effectively to influence meeting outcomes - would be a wasteful and meaningless exercise.

\section{NGO constraints and challenges}

NGOs in the Pacific operate under a number of constraints. Questioning of their legitimacy (Who do they represent? To whom are they accountable?) has become a familiar theme and clearly stems from discomfort or wariness on the part of governments about NGOs playing an advocacy, even worse a watchdog, role. 
Latent tensions that exist between those who see themselves as the legitimate (i.e., elected) leaders of Pacific people and those who are seen, at best, as self-appointed guardians of the public interest are not helped by NGO-bashing. The savage attack made by Professor Ron Crocombe on regional NGOs behind the Pacific Plan statement no doubt provided welcome grist for the mills of those Pacific leaders who might have little regard, much less respect, for NGOs. ${ }^{17}$

While such attitudes might suggest a strict demarcation between the spheres of government and civil society in Pacific states, this is not necessarily the case. Many Pacific governments have had in the past, and still have, close working relations with selected national NGOs and/or NGO umbrella bodies. In some cases, NGOs are aligned so closely to a government they are effectively 'subcontracted' to carry out work it would otherwise do, as in the case of the Soqosoqo Vakamarama in Fiji and Women's Interest Officers. Conservative NGOs overwhelmingly predominate in the Pacific. Mostly charities or apolitical providers of services, they do not present any challenges to the political leadership and usually enjoy an easy relationship with governments.

In the past decade or so, some NGOs in the Pacific assumed strong advocacy roles in support of women's rights, democracy and human rights, peace and development, media freedom, good governance and the rule of law. They have also worked to try to ensure that states meet their obligations in respect of international conventions they have signed onto, or commitments they have agreed to through UN conferences. Women's NGOs in Fiji and Samoa, for instance, played key roles in shadow-reporting on their countries' performance in relation to their obligations to the Convention on the Elimination of all Forms of Discrimination Against Women, while the NGO Coalition on Human Rights in Fiji produced a shadow report on Fiji's Convention on the Elimination of Racial Discrimination obligations.

As organised pressure groups, some of these NGOs came to acquire the kind of negative image once reserved for trade unions, and became the bane of governments. This is especially so for high-profile, outspoken NGOs which regularly use the media to criticise or challenge governments, and/or resort to using the courts if necessary in pursuit of their objectives. If their stance concurs with that of an opposition party or movement they might be branded 'political'. In extreme circumstances, governments might go as far as stripping them of their legal standing, using the conveniently available colonial-era legislation under which NGOs are required to register, which narrowly circumscribes the activities they are legally authorised to undertake. The deregistration of Fiji's Citizens' Constitutional Forum served as a stern lesson to NGOs not to take their watchdog role too far. If the stated commitments to civil society consultations in the Cotonou Agreement and other such treaties are to have any real meaning, however, new legislation that provides proper protection to the diverse range 
of civil society organisations that exist today is urgently required. After the deregistration of the Fijian Forum, the Pacific Concerns Resource Centre commissioned the University of the South Pacific's Institute for Justice and Applied Legal Studies to undertake a review of legislative and regulatory frameworks under which civil society organisations register in ACP member states in the region (Lakshman 2001), but existing legislation, based on the idea of NGOs as 'charities', remains in place. Until they are repealed, NGOs which take on governments remain vulnerable.

Kinship and friendship ties between people in small Pacific Island states, as well as the prevailing 'customs of respect', can make it difficult or uncomfortable for NGOs to confront governments. This is not helped by the revolving door between NGOs and government in some countries and, while it might be defended by many NGOs as an effective 'inside-outside' strategy, it can have the effect of moderating positions taken by NGOs, weakening their ability to hold governments or regional bodies to account. Criticising government tends to bring charges of being 'anti-government', or siding with an opposition party, or 'being political', which NGOs that have a place at the table, so to speak, are not expected to be, although strong NGO leaders retain their autonomy and are not in any way compromised by engaging with governments and intergovernmental bodies.

The resource constraints of small island states are often theorised. These constraints extend to human resources and, among the region's people, the numbers of those with the capacity, critical perspective and inclination to be activists are in short supply. Becoming an activist is a heart and soul thing it comes from an understanding of, and deep concern about, injustice and a dedication to working to change it. In a small society it takes courage to remain an activist, and it often carries considerable personal costs. In today's world of professionalised NGOs, activists are a dying breed. And the Pacific has recently lost some of its leading public intellectuals and activists - Amelia Rokotuivuna and Grace Molisa among them. Some critics and activists have also, sadly, been lost to better paying international organisations within the region or abroad in what some might describe as cooptation. This is particularly the case where critical minds have been lost to institutions involved in reform implementation, where they might take on the agenda of reform out of an honest concern to turn the region around, and address problems that really exist but for which they are no longer exploring alternative 'solutions' to the ones being put before them by the drivers of economic liberalisation.

NGOs have also been adversely affected by funding constraints and over-dependence on donor support. Competition among NGOs for limited grant funds, the influence of donor priorities on NGO agendas, the burden that donor reporting places on NGOs, and the resultant professionalisation of NGOs, have 
all had the effect of changing the nature of Pacific NGOs. While they are better resourced today than ever before, and are encouraged to take on wider social responsibilities as states are urged to narrow theirs, understanding how and why they have come to be so apparently favoured is important. In a Greenpeace report on aid, published in 2002, Teresia Teaiwa wrote, 'In the Pacific, aid surrounds us like the ocean. We are implicated in it and by it' (Teaiwa et al. 2002). A sobering statement, to be sure, but the bottom line surely is that no amount of funding or aid should buy NGO silence.

Challenging economic 'reform' and trade liberalisation requires having a critical perspective on development. There is almost no one today asking questions that used to be asked in the 1970s - the decade of independence for some Pacific Island states - such as 'Development for whom?' and 'Who decides?'. Contrary to the claims of a recent ADB report on poverty (Abbott and Pollard 2004), which commented on the obstacle to 'reform' presented by University of the South Pacific academics who were teaching outmoded development studies at odds with current policies, there are precious few critics of neo-liberalism within academia, at the University of the South Pacific and elsewhere. As such, it's a sad indictment of the ADB authors, and of the ADB, that they should want no dissenting voices or alternative perspectives to be heard in academia. The reality is that critical development theory is slipping off the curriculum, supposedly invalidated by the prevailing 'wisdom' of neo-liberalism. Few who emerge from regional universities are equipped with a critical perspective, nor have they had any experience of working voluntarily with NGOs on issues of concern while they were students. Global issues have tended not to interest or concern students outside of the classroom; student politics in Fiji has been largely corrupted by ethnic and national politics, and 'sitting allowances' paid to students for attending their own council meetings condition them to expect to be remunerated for any involvement in civic affairs. Outside university, with the exception of what feminist organisations are providing, there are no training or mentoring programs for activists interested in broader development issues or public policy.

Despite the constraints on NGO advocacy and activism discussed above, NGOs in the Pacific have unprecedented resources for effective advocacy today. They have the means of accessing information and analyses produced by their counterparts abroad, are able to connect via email to a vast global network of NGOs to seek solidarity support for national campaigns, as well as to the media, intergovernmental bodies, and even political leaders of other states. Indeed, the primary blocks to Pacific NGOs working effectively to counter the forces of neo-liberalism in the region are, firstly, the low priority they individually and collectively give to research and analysis of economic and trade issues - not least because they have yet to acquire understanding and expertise in these issues - and, secondly, the absence of an alternative vision for the future of the Pacific. If they are well-organised, inspired by a clear vision of the kind of 
future they want to build in the Pacific, and equipped with a clear understanding of the political economy of globalisation and neo-liberalism and with the capacity to be effective advocates and watchdogs, civil society organisations in the Pacific region can become a force to be reckoned with. But unless they give priority to working collectively on economic and trade issues - and there is an urgent need to do so as things are moving rapidly in respect to trade liberalisation in the region - NGOs will lose the opportunity to effect any real change in present developments. It is imperative that we reclaim what Amelia Rokotuivuna referred to as the 'spirit of the 1960s and 1970s', when deciding development options meant thinking creatively and deciding for ourselves what kind of society we wanted to build.

\section{References}

Abbott, David and Steve Pollard. 2004. Hardship and Poverty in the Pacific. Asian Development Bank.

Alley, Roderic. 2000. The Domestic Politics of International Relations; Cases from Australia, New Zealand and Oceania. Aldershot, UK, and Burlington, VT: Ashgate.

Cardoso, Fernando Henrique. 2003. 'Civil Society and Global Governance.' Contextual paper prepared by the panel's chairman. High Level Panel on UN-Civil Society.

Choudry, Aziz. 2002. 'The ADB — “Governing" The Pacific?' Paper produced for Focus on the Global South, April.

Boaventura de Sousa Santos, Início. 2003. The World Social Forum: Toward A Counter-Hegemonic Globalization. Presentation at the XXIV International Congress of the Latin American Studies Association, Dallas, March 27-29, http://www.ces.uc.pt/bss/fsm.php

Field, Michael. 2005. 'Pacific Rumblings.' The Dominion Post. Tuesday, October $11,2005$.

Firth, Stewart. 2000. 'The Pacific Islands and the Globalization Agenda.' The Contemporary Pacific, 12, 1. pp. 178-92.

Fisher, William F. and Thomas Ponniah. 2003. Another World is Possible: Popular Alternatives to Globalisation at the World Social Forum. Nova Scotia: Zed Books, Fernwood Publishing Ltd, and London and New York: Zed Books.

Forsyth, David and Nii-K Plange. 2001. Social Impact Assessment of Membership of the Pacific Free Trade Area. Suva: University of the South Pacific.

Fry, Greg. 1997. 'Australia and the South Pacific: the Rationalist Ascendancy.' In J. Ravenhill and J. Cotton (eds), Seeking Asian Engagement: Australia 
Globalisation and Governance in the Pacific Islands

in World Affairs 1991-95, Melbourne: Oxford University Press. Pp. 314-34.

Fry, Greg. 2006. 'Whose Oceania? Contending conceptions of community in Pacific region-building.' In Michael Powles (ed.), Pacific Futures Towards A Pacific Community?, Canberra: Pandanus Books.

Gay, Daniel and Roy Mickey Joy. n.d. Vanuatu. Port Vila: Overseas Development Institute and Vanuatu Department of Trade, Industry and Investment and Bangkok: ESCAP.

http://www.unescap.org/tid/publication/t\&ipub2278_van.pdf

Hamed, Omar. 2005. 'Neo-Colonialism Ratified At Pacific Islands Forum.' In Just Focus - Youth Focus for a Just World, http://www.justfocus.org.nz/articles/2005/11/04/ neo-colonialism-ratified-at-pacific-islands-forum/

Hughes, Helen. 2003. 'Aid Has Failed the Pacific.' Centre for Independent Studies, Issue Analysis, No. 33, May 7.

Kelsey, Jane. 2004a. Big Brothers Behaving Badly: The Implications for the Pacific Islands of the Pacific Agreement on Closer Economic Relations (PACER). Pacific Network on Globalisation (PANG), Interim Report.

Kelsey, Jane. 2004b. A People's Guide to PACER - The Implications for the Pacific Islands of the Pacific Agreement on Closer Economic Relations (PACER). Suva: Pacific Network on Globalisation (PANG).

Kelsey, Jane. 2004c. 'Acceding Countries As Pawns In A Power Play: A Case Study Of The Pacific Islands.' Focus on the Global South, August 23, 2004, http://www.focusweb.org/content/view/442/36/

Kelsey, Jane. 2005a. A People's Guide To The Pacific's Economic Partnership Agreement, Negotiations between the Pacific Islands and the European Union pursuant to the Cotonou Agreement 2000. Suva: World Council of Churches Office in the Pacific. http://www.arena.org.nz/REPA.pdf

Kelsey, Jane. 2005b. 'Reflections on Strengthening Regional Cooperation Through Enhanced Engagement with Civil Society', PIAS-DG, USP.

Lakshman, C. 2001. Review of Legislative and Regulations Framework Governing the Establishment and Legal Status of the Civil Society Sector in the Pacific Member States of the ACP. Suva: IJALS, University of the South Pacific and Pacific Concerns Resource Centre.

Murray, Warwick. 1998a. 'The Price of Putting All Your Pumpkins in One basket: The Tongan Squash Export Boom.' Suva: Te Amokura, Development Studies Centre, University of the South Pacific. 
Murray, Warwick. 1998b. 'The Global Agro-Food Complex, Neo-Liberalism and Small Farmers in Chile: Lessons for the Pacific Islands?' The Journal of Pacific Studies, 22, 1\&2. pp 27-60.

Oxfam New Zealand. 2004. Annex to the Submission by Oxfam New Zealand to the Foreign Affairs, Defence and Trade Committee on the Inquiry into New Zealand's Relationship with Tonga. September.

Oxfam New Zealand. 2005. Make Extortion History.

Pacific Magazine Online. 'Moratorium Call for Pacific Plan.' Thursday September 15, 2005, http://www.pacificislands.cc/pina/pinadefault2.php?urlpinaid $=16889$

Pacific Network on Globalisation PANG. 2002. 'What's in it for the Pacific? A critical response to PICTA, PACER and the Pacific Islands Forum's Social Impact Assessment.' Fiji Sun, February 18.

Pacific Region NGOs. 2005. Civil Society Statement on Pacific Plan. September.

Slatter, Claire. 1989. 'Anti-Unionism in Fiji.' Social Alternatives, 8 (2).

Slatter, Claire. 1991. 'Economic Recovery on the Backs of Women Workers: Women and tax free enterprises in Fiji.' Review (Suva: School of Social and Economic Development, University of the South Pacific), 12 (19).

Slatter, Claire. 1994. 'Banking on the Growth Model? The World Bank and Market Policies in the Pacific.' In 'Atu Emberson-Bain (ed.), Sustainable Development or Malignant Growth? Perspectives of Pacific Island Women, Suva: Marama Publications. pp. 17-36.

Slatter, Claire. 1996. 'None of our Business? Women and Political and Economic Issues in the 1990s.' The Pacific Journal of Theology, Series II, No. 15. pp. 64-72.

Slatter, Claire. 2001. 'Economic restructuring in the Pacific: external agendas, internal impacts and growing dissent.' Tok Blong Pasifik.

Slatter, Claire. 2003. 'A Commentary on Helen Hughes'“Aid Has Failed the Pacific" (Centre for Independent Studies, Issue Analysis, No. 33, 7 May 2003).' USP Beat, Vol. 3, Issue 10, July 29, 2003. http://www.dev-zone.org/kcdocs/5938slatter.html

Slatter, Claire. 2006. 'Neo-liberalism and the disciplining of Pacific Island States - the dual challenges of a global economic creed and a changed geo-political order.' In Michael Powles (ed.), Pacific Futures, Canberra: Pandanus Books.

Standish, Bill. 2001. 'Papua New Guinea in 1999-2000.' Journal of Pacific History, 36 (3). pp. 285-98. 
Stromquist, Nelly, P. n.d. 'The Impact of Globalization on Education and Gender: An Emergent Cross-National Balance'. Rossier School of Education, University of Southern California. http://www.edu.unp.ac.za/kenton/ programme/papers/Impact_of_Globalization.htm

Submission of Oxfam New Zealand to the Foreign Affairs, Defence and Trade Committee on the Inquiry into New Zealand's Relationship with Tonga, April 2, 2004.

Sutherland, William. 2000. 'Global Imperatives and Economic Reform in the Pacific Island States.' Development and Change, 31 (2). pp. 459-80.

Sutherland, William with Robbie Robertson, Malakai Koloamatangi and Tarcisius Kabutaulaka. 2005. Strengthening Regional Cooperation Through Enhanced Engagement with Civil Society. Suva: Pacific Institute for Advanced Studies in Development and Governance, USP.

Tate, Belinda. 2005. The NGO Environment in Samoa: A case study of the socio-political environment's impact on local NGOs. MA thesis, Development Studies, School of Earth Sciences, Victoria University, Wellington.

Taylor, Viviene. 2000. Marketisation of Governance: Critical Feminist Perspectives from the South. A Development Alternatives with Women for a New Era (DAWN) publication. Cape Town: SADEP, University of Cape Town.

Teaiwa, Teresia K., Sandra Tarte, Nic Maclellan and Maureen Penjueli. 2002. Turning the Tide: Towards a Pacific solution to conditional aid. Suva and Sydney, Greenpeace Australia Pacific.

United Nations. 2003. The UN System and Civil Society - An Inventory and Analysis of Practices. Background Paper for the Secretary-General's Panel of Eminent Persons on United Nations Relations with Civil Society, May.

World Bank. 1991. Towards Higher Growth in the Pacific Island Economies: Lessons from the 1980s, Vol. 1: Regional Overview; Vol. 2: Country Surveys.

World Bank. 1993. Pacific Island Economies: Toward Efficient and Sustainable Growth. Vol 1: Overview. Report No. 11351-EAP. March 8, 1993.

World Bank. 1995. Pacific Island Economies: Building a Resilient Economic Base for the Twenty-First Century. Report No. 13803-EAP. February.

World Bank. 2002. Embarking on a Global Voyage: Trade Liberalisation and Complementary Reforms in the Pacific. Pacific Islands Regional Economic Report, No. 24417-EAP. Poverty Reduction and Economic Management Unit, East Asia and Pacific Region.

World Council of Churches. 2001. Island of Hope - The Pacific Churches' Response On Alternatives To Economic Globalisation. 


\section{ENDNOTES}

1 The World Bank first introduced a concern with the issue of 'governance' in a 1989 report on subSaharan Africa (Sub-Saharan Africa: From Crisis to Sustainable Growth), a concern which, after the publication of its World Development Report in 1997, entitled The State in a Changing World, would come to dominate World Bank reports on the economies of developing regions and spark a major discourse on governance in academic and development circles in the 1990s.

2 See The UN System and Civil Society (2003) for a concise but comprehensive history and analysis of NGO involvement in UN processes. It records how major NGO campaigns, such as those against apartheid, for an international code of conduct for the marketing of breast-milk substitutes, for increased official development aid, and to minimise the negative social impacts of structural adjustment, earned them respect within the UN system, and highlights the September 1994 statement by then UN SecretaryGeneral, Boutros Boutros-Ghali, that NGOs were 'a basic form of popular participation in the presentday world. Their participation in international organizations is, in a way, a guarantee of [their] political legitimacy', and that the UN was no longer a forum for sovereign states alone - that 'NGOs are now considered full participants in international life'. See also Edwards, M. and A. Fowler (eds), 2002, The Earth Scan Reader on NGO Management, London: Earthscan, which records how, by the 1990s, European and North American thinking on civil society and its contribution to social and economic development had begun to penetrate donor organisations and multilateral institutions including the World Bank (see Tate 2005).

3 The demand for reform of global governance institutions was linked to a curious convergence of discourses from the left and the right on the need for institutional reform of the State (see Taylor 2000).

4 The WSF brings together representatives of social movements which waged historic struggles for political equality and self-determination, peace and justice in the last century (e.g., the labour movement, independence and sovereignty movements, civil and political rights movements, movements against racism and apartheid, peace, disarmament and environmental movements and women's and indigenous peoples' movements) and those of more recent vintage (e.g., minority rights movements, movements for the cancellation of Third-World Debt and controls on finance capital, campaigns to end militarism, violence against women and trafficking, human rights movements and movements against fascist or fundamentalist extremism). The presence of some left-wing parties and political liberation movements primarily from Latin America in the WSF, and also of some reactionary political elements, raised questions and met with some resistance within the WSF, although the WSF's determination to remain open to all groups means that a wide spectrum of interests can be expected to find a place within it.

5 Blindness among the WSF's otherwise progressive (left-wing) organisers to the assault on women's rights from rising neo-conservatism, virulent religious and cultural fundamentalism and aggressive militarism led feminists within the WSF to caucus, strategise and, from 2004, organise a separate event before the WSF, the International Feminist Dialogues, which draws representatives from most of the leading international and regional feminist networks.

6 In 1998, 11 donor agencies were funding or had assisted public sector reform projects in one or more of the following seven countries of the region: Cook Islands, FSM, Fiji, Republic of the Marshall Islands, Vanuatu, Samoa and Tonga. These included the IMF, the Pacific Financial Technical Advisory Centre, WHO, UNDP, the EU, AusAID, the New Zealand Ministry of Foreign Affairs and Trade, the Japanese Development Agency, French aid agencies, USAID and other US agencies and ESCAP Pacific Operations Centre.

7 In the past 15 years, free market advocates within Australian and New Zealand academia have been producing analyses of Pacific Island economies and states, some of them commissioned or otherwise supported by their governments, or written for multilateral institutions such as the World Bank and the ADB. (See Fry 1997.) A recent series of hardline analyses of Pacific Island economies and states, written by former Director of The Australian National University's National Centre for Development Studies (NCDC), Helen Hughes, has been published by the Sydney-based, right-wing policy think tank, the Centre for International Studies. See Hughes (2003), and Slatter $(2003,2004)$ for a critique.

8 See Gay and Joy (n.d.) for a critical perspective on Vanuatu's ADB-funded Comprehensive Reform Program (CRP) through which Vanuatu's external debt grew to 31.2 per cent of GDP by 2002. Misgivings about ADB's structural adjustment lending to Pacific Island states were also expressed privately to the author by a former ADB consultant who disclosed that the ADB had saddled the island states with huge debts, that it was now having difficulty placing loans funds allocated for the Pacific as Pacific Island states were wary, and PNG and Solomon Islands had already announced that they did not want any more ADB loans.

9 See Sutherland (2000) and Slatter (2004) for further discussion of the role of the Forum Secretariat. 
10 Sutherland (2000) documents critical statements made by the FSM President, Jacob Nena, when opening the 29th South Pacific Forum in Pohnpei in 1998, and Roderic Alley (2000) records Marshall Islands Finance Minister de Brum's publicly expressed irritation at the heavy hand of the ADB; while Choudry (2002) records the Prime Minister of Niue, Sani Lakatani's, pointed statements about the Pacific Islands' loss of sovereignty in an emerging 'new order of colonialism'. The most vociferous and bitter criticism has come from the PNG Prime Minister, Michael Somare.

11 See Kelsey (2004a) for an exposé of how Australia and New Zealand bullied their way into securing PACER.

12 Among University of the South Pacific academics at the time, only the published work of Firth (2000), Murray (1998a, 1998b) and Slatter $(1989,1991,1994,1996,2001)$ took a critical perspective of economic globalisation.

13 The planned retrenchment of 2,000 soldiers would have cost 70 million kina in compensation payments. The plans, which included the disbanding of the civil engineering battalion and sale of Murray Barracks and the naval establishment in Lombrum in Manus, had not involved any consultation or explanation for those affected, according to Bernard Narakobi.

14 According to Kelsey (2004c), Vanuatu made commitments to liberalise professional services, basic and value-added telecommunications services, environmental, wholesale, retail, insurance, banking services, hotels and restaurants, primary, secondary, higher, adult and other education services, and sewerage, refuse disposal, sanitation and general construction services.

15 See Michael Field (2005) and Elise Huffer's critique in this volume.

16 Pacific regional NGOs which signed the statement were: Council of Pacific Education, Disabled People's International, Fiji Women's Crisis Centre, Pacific Women's Network Against Violence Against Women, Foundation of the People's of the South Pacific International, Greenpeace Pacific, South Pacific Oceanic Council of Trade Unions, Pacific Concerns Resource Centre, Pacific Conference of Churches, Pacific Foundation for the Advancement of Women, Pacific Islands Broadcasting Association, Pacific Islands Association of Non-Government Organisations, World Council of Churches - Pacific, and the World Wide Fund for Nature. Of these organisations, only one, the Fiji Women's Crisis Centre, is a national organisation.

17 Crocombe disparaged the NGOs as being Suva-based and therefore not 'regional' and accused them of capturing massive resources for themselves from donors abroad by misrepresenting themselves as regional, and of purporting to represent people in the region. 